\title{
A Review of Studies from the Last Twenty Years on Plant-Arbuscular Mycorrhizal Fungi Associations and Their Uses for Wheat Crops
}

\author{
Paola Ganugi *(D), Alberto Masoni, Giacomo Pietramellara and Stefano Benedettelli \\ Department of Agriculture, Food, Environment and Forestry, University of Florence, Piazzale delle Cascine 18, \\ 50144 Florence, Italy; alberto.masoni@unifi.it (A.M.); giacomo.pietramellara@unifi.it (G.P.); \\ stefano.benedettelli@unifi.it (S.B.) \\ * Correspondence: paola.ganugi@unifi.it
}

Received: 22 October 2019; Accepted: 1 December 2019; Published: 3 December 2019

check for updates

\begin{abstract}
The aim of this work was to summarize the most recent research focused on the study of plant-arbuscular mycorrhizal fungi (AMF) symbiosis, both in a generic context and in the specific context of wheat cultivation. Taking into account the last 20 years, the most significant studies on the main plant advantages taken from this association are reviewed herein. Positive advances that have been reported stem from the mutualistic relationship between the plant and the mycorrhizal fungus, revealing better performance for the host in terms of nutrient uptake and protection from salinity, lack of water, and excess phytotoxic elements. Mycorrhiza studies and the recent progress in research in this sector have shown a possible solution for environmental sustainability: AMF represent a valid alternative to overcome the loss of biological fertility of soils, reduce chemical inputs, and alleviate the effects of biotic and abiotic stress.
\end{abstract}

Keywords: mycorrhizae; nutrients uptake; salinity; drought; heavy metals; pathogens; soil aggregation; wheat

\section{Introduction}

A mycorrhiza (from Greek, mykos: fungus and Rhiza: root) is a particular symbiotic association between a higher plant and a fungus that is located in the plant root apparatus and extends into the rhizosphere and the surrounding soil.

This symbiosis, named "mycorrhiza" by Frank in 1885 [1], has become a very interesting research object for the agronomic sector, with particular attention to its positive effects on the most important crops, mainly thanks to the studies of Peyronel in Italy, Melin in Sweden, and Harley in England [2]. Nowadays, we are aware that besides being present in almost all plants in good vegetative conditions [3], mycorrhizae represent a form of "biological fertilization" [4], with the results being very effective for plants, especially in conditions of abiotic or biotic stresses.

According to the different associations between plant and fungus, mycorrhizae are classified into three groups: ectomycorrhiza, endomycorrhiza, and ectoendomycorrhizae (with mixed behavior between ectomycorrhiza and endomycorrhizae) [2]. Recently, research attention has been focused mostly on the second group.

Ectomycorrhiza are formed by Basidiomycetes and Ascomycetes fungi with the roots of plants from cold temperate regions, including firs, pines, and larches in borealis and subalpine forests, and oaks and poplars in deciduous forests [5]. The fungus, which is an obligatory symbiont, forms a mantle of hyphae around the root and completely envelops the root tip but never enters the inside of the cells [6]. 
Endomycorrhiza differ from the previous type in structure: the hyphae of the fungus not only grow inside the root of the plant, but penetrate the root cell walls and become enclosed in the cell membrane as well [7]. This makes for a more invasive symbiotic relationship between the fungus and the plant. Endomycorrhiza have further been classified into five major subgroups-arbuscular, ericoid, arbutoid, monotropoid, and orchid mycorrhizae [8]—-but arbuscular mycorrhizae (AM), which are the most ubiquitous in nature and affect many plants (both cultivated and living in natural ecosystems), are the most debated and studied in agriculture research [9].

The fungi developing into AM belong to the phylum Glomeromycota and form mutualistic relationships with over $80 \%$ of all vascular plants [10]; once in contact with the host's root, they penetrate through the epidermis and establish their hyphae in the cortical parenchyma [11]. The penetration of the fungus inside the root surface can take place via three different modalities: it can form an appressorium, from which intracellular hyphae originate; it can penetrate through a radical hair; or it can enter across the cells of external layers that are often dead and flake off [2]. At this point, the hyphae, deepening in the root, abundantly colonize the cells and undergo intense branching, forming arbuscules with a life cycle of 7-12 days [12], which act as the site for fungus/plant metabolite exchange and for the accumulation of reserve nutrients [13]. The fungus does not come into contact with the cytoplasm of the host plant but is always separated from the host cell plasmalemma that is absorbed during the penetration and involved in all developmental stages of the symbiotic interaction [14] (Figure 1). These fungi are obligate symbionts and form a mutualistic symbiotic association with the plant through an exchange of substances between them: the fungus receives carbon to complete its life cycle and, at the same time, it provides nutritional benefits to the plant [15]. Of the carbohydrates produced by the plant through photosynthesis, $10 \%$ to $40 \%$ can be absorbed by mycorrhizal fungi [16]. Moreover, extraradical mycelial networks seem to maintain their ability to establish mycorrhizal symbioses with plants as long as five months after shoot removal, adsorbing nutrients released from dead roots [17].

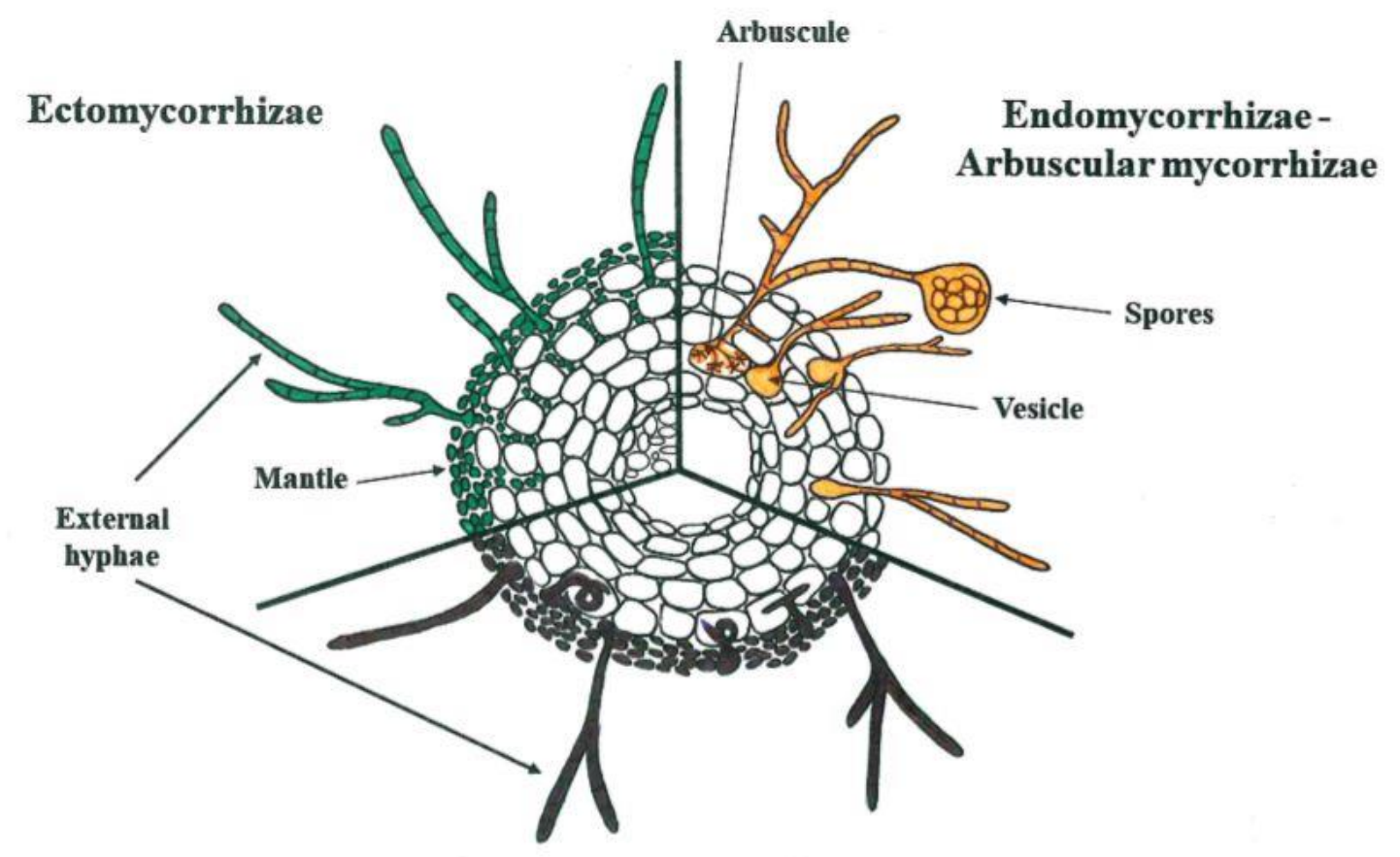

Ectoendomycorrhizae

Figure 1. Different associations between a mycorrhizal fungus and plant roots. Arbuscular mycorrhizal fungi (on the right) penetrate the cortical cells of the root, forming structures such as arbuscules and vesicles. Ectomycorrhizal fungi (on the left) completely cover the plant root system with a mantle of fungal tissue, and the hyphae surround the plant cells within the root cortex. With ectoendomycorrhizal fungi (bottom), the fungus mantle is formed but the hyphae may also penetrate the plant cells. 
Currently, many scientific works have involved multidisciplinary approaches to understanding arbuscular mycorrhizal fungi (AMF) symbiotic association, underlining the importance of their use in sustainable and organic agriculture in relation to the most cultivated crops.

The notable relevance of wheat in the Mediterranean human diet, with total production of 756 million tons for 2017-2018 (FAO 2018), has motivated and encouraged research towards the experimental use of mycorrhizal fungi in order to guarantee the better performance of plants. This direction has two principal goals: firstly, a lower dependence on chemical fertilizers and pesticides, and secondly, crop protection from abiotic stress (lack of water, salinity, excess phytotoxic elements).

\section{Uptake and Translocation of Soil Nutrients}

Many studies have examined the key role of arbuscular mycorrhizal fungi (AMF) in nutrient uptake and translocation and discovered a plant root surface area increment.

First, the ability of mycorrhizal hyphae to extend and explore a greater area of soil than the host plant's roots can reach has been demonstrated [18]. The fungus seems to be a great help in the acquisition of soil nutrients, reaching micro and macro elements which the plant alone could not reach. In this way, the depletion zone created via a plant's rapid nutrient uptake in the proximity of its root system [19] can be bridged, and an adequate supply of nutrient elements is translocated to the plant [20].

Secondly, fungal hyphae dimensions positively influence nutrient uptake: their narrow diameter $(2-20 \mu \mathrm{m})$ allows them to access small pores that are unreachable for plant roots [21], with important implications in terms of water and micronutrient absorption [22]. In this context, Drew et al. [23] evidenced a further mycorrhizal ability to adjust the hyphal diameter depending on the soil pore size and, in this way, provide for plant nutrition independently of soil texture.

Some other studies have linked the increased plant acquisition of mineral nutrients to AMF production of some organic acids and enzymes which represent, respectively, a source of phosphorus and a means to depolymerize organic nitrogenous polymers and to take up nitrogen from secondary sources of organic matter like dead microbial biomass [24,25].

The positive effect of mycorrhizae on wheat plants' response to nutrient uptake has been recently well documented by many researchers. A meta-analysis conducted on 38 published field trials with 333 observations highlighted the beneficial effect of field AMF inoculation on wheat dry weight and $\mathrm{P}$, $\mathrm{N}$, and Zn uptake [26].

Concerning zinc ( $\mathrm{Zn}$ ) uptake, AMF contribution was tested by Ma et al. [27], who revealed a Zn concentration 1.13-2.76 times higher in wheat plants treated with Funneliformis mosseae and Rhizophagus intraradices, and by Ryan and Angus [28], who showed an increase of Zn absorption with Rhizophagus irregularis and Scutellospora calospora administration to the plant. Moreover, a positive correlation between grain $\mathrm{Zn}$ concentration and the level of colonization by AMF was suggested in a study by Ryan et al. [29].

Advantageous results for phosphorus (P) nutrition were found with Rhizophagus irregularis inoculum and spring wheat (Triticum aestivum), supporting a mycorrhizal fungi contribution of more than $50 \%$ of the P absorption by the plant [30], and with Funneliformis mosseae and durum wheat (Triticum durum, cv. Petra), showing a plant dependency on mycorrhizae for P uptake [31]. High differences in P plant acquisition were also obtained in Claroideoglomus etunicatum inoculated plants (Triticum aestivum, cv. Otto), reflecting the beneficial mineralizing phosphatase (P-ase) effect of the AM-fungus-colonized roots. The first evidence of the positive interactions among AMF and bacteria isolated from their spores was provided by Battini et al. [32], who showed increased P uptake via a mycorrhizal pathway in maize plants with a particularly efficient strain, Streptomyces sp.

In field conditions, a synergistic effect of plant-growth-promoting rhizobacteria and AMF on wheat P uptake was observed: a higher P content (67.8 $\mathrm{mg} \mathrm{plant}^{-1}$ ) was observed with the co-inoculation of Azotobacter chroococcum with Bacillus spp. and Rhizophagus fasciculatus [33]. 
Enhanced selenium (Se) content in wheat grain through inoculation with AM fungi was documented by Luo et al. [34], who showed, after inoculation with Diversispora epigaea (formerly Glomus versiforme) or Funneliformis mosseae, a significant increase in selenate and selenite uptake by the wheat roots in hydroponic experiments. Positive results for Se uptake were also found in an experiment on wheat (Triticum aestivum, cv. Otto) by Durán et al. [35], where applications of selenobacteria strains (Stenotrophomonas sp. B19, Enterobacter sp. B16, Bacillus sp. R12 and Pseudomonas sp. R8) with the AM fungus Glomus claroideum resulted in a $23.5 \%$ higher $\left(725 \mathrm{mg} \mathrm{kg}^{-1}\right)$ selenium content than that in non-mycorrhizal plants $\left(587 \mathrm{mg} \mathrm{kg}^{-1}\right)$.

A recent study by Blackwell et al. [36] investigated inoculation with AMF combined with biochar treatment to improve wheat mineral nutrition. This research showed how biochar-mineral complexes (BMCs), coupled with the AM fungus, increase the nutrient uptake of wheat (Triticum aestivum, cv. Wyalkatchem), particularly for N, P, K, S, and Zn. These results confirm Saito and Marumoto's [37] explanation that biochar influences microbial activity by providing a weakly alkaline microhabitat within the pore spaces.

\section{Abiotic Stresses}

Several studies on abiotic stresses have shown how human activities connected to agriculture (excessive use of pesticides and fertilizers, irrigation) and construction (deforestation, waste material diffusion) have negatively affected plant growth, health, and yield, causing significant and catastrophic production losses [38,39]. Plant responses to stresses involve a generic pathway that starts from stress signal acquisition by the membrane receptor and ends with the expression of genes, the products of which can provide plant defense, directly or indirectly [40]. Nevertheless, many studies on AM symbiosis have confirmed the contribution of the involved fungus in helping the plant to resist abiotic stress-such as drought, salinity, and heavy metal contamination-through the implementation of various mechanisms.

\subsection{Salinity Stress}

High salt concentrations in the soil make it harder for roots to extract water and can be toxic to plant functions [41], resulting in some negative outcomes, such as ethylene production, plasmolysis, nutrient imbalance, interference with photosynthesis, and the production of reactive oxygen species (ROS) [42]. Osmotic adaptation, represented by the accumulation of compatible solutes (such as proline and glycine betaine) within the plant cells, represents a physiological mechanism for the plant that allows it to maintain a gradient of water potential between the cells without a decrease in turgor or growth [43]. However, many recent scientific works have evidenced the existence of salt-tolerant AMF species that, being able to maintain good efficiency in root colonization and symbiosis formation, help the plants to overcome the salinity problem. In particular, scientists refer to four different AMF abilities to alleviate salt stress, which are the following:

(1) Higher water uptake: mycorrhizal hyphae can better expand into the soil, taking up more water and preventing plant dehydration and turgor loss-two consequences of salinity compromising the water status of the plant [44].

(2) Increased mineral nutrition linked to maintaining a high $\mathrm{K} / \mathrm{Na}$ ratio [45]: under osmotic stress conditions, the soil $\mathrm{Na}^{+}$concentration is very high and negatively interferes with other various transporters in the root plasma membrane, such as $\mathrm{K}^{+}$selective ion channels [46]. As a consequence, the uptake of mineral nutrients $\left(\mathrm{P}, \mathrm{K}, \mathrm{Fe}, \mathrm{Cu}\right.$, and $\mathrm{Zn}$ ) is reduced and, in particular, the $\mathrm{Na}^{+} / \mathrm{K}^{+}$ ratio becomes very high, interrupting various enzymatic processes and protein synthesis [47]. Plant association with AMF, thanks to their higher soil exploration capacity, showed a total mineral nutrition increase with great $\mathrm{K}^{+}$accumulation, helping the plants to maintain a lower $\mathrm{Na}^{+} / \mathrm{K}^{+}$ratio and in this way avoid damage to their biological functioning [48]. 
(3) Intense production of compatible organic solutes: low-molecular-weight and highly soluble compounds, such as proline, glycine, betaine, and soluble sugars, are accumulated to higher levels in AM plants and appear to be positively correlated to fungi plant colonization $[49,50]$. Production of these solutes can contribute to cellular osmotic adjustment thanks to their key role in detoxifying ROS, protecting membrane integrity, and stabilizing enzymes/proteins [51].

(4) Antioxidant enzyme activity enhancement: several studies have suggested that AM symbiosis intensifies enzyme system activity in ROS detoxification, including that of peroxides, superoxide, hydroxyl radicals, and singlet oxygen and alpha-oxygen, the production of which in plants is strongly influenced by stress factors such as salinity. The effects induced by these compounds on cell metabolism, such as DNA damage, the oxidation of polyunsaturated fatty acids in lipids and of amino acids in proteins, and the deactivation of specific enzymes, appear to be reduced in AM plants, which show generally lower levels of oxidative damage.

Almost all research regarding the role of mycorrhizal symbiosis in enhancing wheat plant tolerance, growth, and yield under salinity stress has been conducted under growth chamber conditions or in a greenhouse, using sterilized soil and salty water or salty soil.

At the greenhouse of the National Research Center of Giza (Egypt), Talaat and Shawky [52] studied the key role of AMF in protecting two wheat cultivars (Triticum aestivum, cv. Sids 1 and cv. Giza 168) against the detrimental effect of salinity: inoculation with fungi showed their ability to improve plant productivity; the membrane stability index; photochemical reactions during photosynthesis; the concentrations of $\mathrm{N}, \mathrm{K}^{+}$, chlorophyll, carbohydrates, and protein; and the relative water content (RWC). Abdel-Fattah and Asrar's [53] investigation showed that arbuscular mycorrhizal inoculation (particularly Funneliformis mosseae) significantly alleviated the harmful effects of salt stress on wheat plants (Triticum aestivium, cv. Henta) grown in saline soil, reducing Na uptake; increasing P, N, K, and $\mathrm{Mg}$ contents; and stimulating photosynthetic pigments and some metabolic contents of the wheat plants. Positive results in salt stress conditions were found in pot experiments on Triticum aestivum cv. Purna HI-1544, with dual treatment with AM fungi and spermine revealing a great enhancement of wheat yield [54], and a mixed starter culture of native AMF culture (mainly comprising Rhizophagus intraradices, Funneliformis mosseae, and Funneliformis geosporum) resulting in mitigation of the metabolic inhibition of photosynthesis through the maintenance of PSI and PSII integrity and stability [55].

Field experiments regarding the effects of arbuscular mycorrhiza (AM) on wheat plant growth under salinity are very rare, but the beneficial effects under controlled conditions seem to be confirmed. Daei et al. [56] conducted a field experiment in Karaj (Iran) testing and verifying the role of Glomus etunicatum, Glomus mossae, or Glomus intraradices in significantly increasing the growth and nutrient uptake of the mutated Tabasi line (produced by the Institute of Agricultural, Medical and Industrial Research, Tehran, Iran). This experiment was reproduced using the same AM fungi on the same wheat line by Mardukhi et al. [57], confirming enhanced plant capacity in absorbing minerals such as N, Ca, $\mathrm{Mg}, \mathrm{Fe}, \mathrm{Cu}$, and $\mathrm{Mn}$ from salty soil in Alborz province (Iran).

\subsection{Drought Stress}

Drought represents for plants one of the most common abiotic stresses affecting growth and development [58], resulting in a negative impact on plant survival, development, and productivity [59]. Wilting of the plants and reductions in the net photosynthesis rate, stomatal conductance, water use efficiency, and relative water and total chlorophyll contents are the principal symptoms of drought stress [60]. In addition, the electron transport system is impaired, leading to the formation of activated oxygen [61] and plant stomata closing, resulting in decreased $\mathrm{CO}_{2}$ uptake and an increase of reduction equivalents. As a consequence, the photosynthetic apparatus is damaged by ROS accumulation, and metabolic processes become involved in the synthesis of secondary plant products (isoprenoids, phenols, or alkaloids) [62]. Many studies on arbuscular mycorrhizal fungi have revealed the importance of their symbiosis with plants in alleviating the negative effects induced by drought [63] and have 
attributed to these microorganisms a key role in the response to this stress [64,65], principally in relation to the following:

(1) Maintenance of water uptake: Mycorrhizal hyphae enter deeper into the soil and explore a great volume in search of water, helping to keep the plant watered [66];

(2) Osmotic adjustment: Some processes like stomatal opening, cellular expansion, and growth are maintained by the mycorrhizal fungus activity, allowing the cells to maintain turgor [67];

(3) Biosynthesis of trehalose: This sugar, consisting of two molecules of glucose and synthesized by the fungus, may contribute to protecting the plant from a lack of water, preserving biological nitrogen fixation and improving the plant's tolerance of drought stress [68,69];

(4) Antioxidant level increase: The concentrations of many antioxidant compounds, such as superoxide dismutase, catalase, and peroxidase, appear to be enhanced in plants colonized by mycorrhizal fungi, resulting in the reduced presence of ROS such as singlet oxygen, superoxides, hydrogen peroxide, and hydroxyl radicals [70].

Expression of drought-related genes in host plants: Mycorrhizal functions may stimulate the expression of some plant genes, including aquaporin genes, the 1-pyrroline-5-carboxylate synthetase ( $\mathrm{p} 5 \mathrm{cs}$ ) gene encoding a rate-limiting enzyme in the biosynthesis of proline, and the 9-cis-epoxycarotenoid dioxygenase (nced) genes encoding a key enzyme in the biosynthesis of abscisic acid [71]. As a consequence, respectively, the flow of water molecules inside or outside the cells is accelerated [72], one antioxidant action is developed [73], and the stomata are closed to avoid water loss [74].

Inoculation with arbuscular mycorrhizal fungi has been well reported to stimulate wheat growth under drought stress conditions. A metabolomic analysis by Bernardo et al. [75] in a water deficit regime on Triticum durum and Triticum aestivum wheat cultivars supported the hypothesis of mycorrhizal fungi involvement in enhancing plant response to water stress: inoculation with Funneliformis mosseae significantly improved the plants' biomass production, resulted in a positive trend in water use efficiency (WUE), and reduced oxidative damage, resulting in the root accumulation of compounds known to play an antioxidative role by directly reacting with ROS. Equally, inoculation of Buck Pronto cultivars (Triticum aestivum) with Glomus claroideum alleviated the deleterious effects of drought stress, revealing significant increases in total dry weight, relative water content (RWC), and leaf chlorophyll content [76]. Field experiments under water-stressed conditions were conducted in Lubbock (Texas) on Steardy (drought-sensitive) and TAM-105 (drought-tolerant) winter wheat cultivars: inoculation with Funneliformis mosseae or Claroideoglomus etunicatum provided an important enhancement of the yield in both cultivars [77]. Triticum aestivum plants, exposed to water stress and grown in soil inoculated with a mixed starter culture of AMF (Rhizophagus intraradices, Funneliformis mosseae, F. geosporum), showed less damage to the structure and function of PSII and PSI systems and exhibited an increase in RWC for both leaf and soil, indicating the ability of AMF hyphae to penetrate deep into the soil and provide moisture to the plants [78]. Finally, beneficial effects of co-inoculation with biochar and mycorrhizal fungi on crop N and P supply for dryland wheat production were reported by Solaiman et al. [79].

\subsection{Heavy Metal Stress}

Some metal elements, such as copper $(\mathrm{Cu})$, iron $(\mathrm{Fe})$, manganese $(\mathrm{Mn})$, nickel $(\mathrm{Ni})$, chromium $(\mathrm{Cr})$, molybdenum $(\mathrm{Mo})$, antimony $(\mathrm{Sb})$, and zinc $(\mathrm{Zn})$, are required by plants for numerous enzyme-catalyzed or redox reactions, in electron transfer, and in nucleic acid metabolism [80]. However, high concentrations of them can interfere with essential enzymatic activities by modifying protein structure or by replacing an essential element, resulting in deficiency symptoms such as chlorosis, reduced seed germination [81] and root growth, effects on both photosystems [82], and cell cycle arrest. Nowadays, anthropogenic activities such as industrial waste diffusion and fertilizer application are responsible for heavy metal accumulation in the groundwater and on the soil surface and for subsequent diffusion into plant root systems, representing a real source of stress for these organisms [83]. 
Nevertheless, arbuscular mycorrhizal fungi seem to have a key role in helping the plants in heavy-metal-contaminated areas. First of all, AM fungal hyphae have a great ability to explore the soil and, thanks to their surface area for the accumulation of toxic metals, they represent an excellent adsorptive site for the accumulation of cations that prevent entry to the plants [84]. In the extraradical hyphae, heavy metals are frequently precipitated by proteins called glomalines, which are produced by the fungus [85]. Secondly, another positive effect of this symbiosis is localized in the soil where AM fungi release exudates containing citric acid, malic acid, lactic acid, etc. These organic acids form complexes with the metals and reduce their concentration in the soil system [86].

The beneficial effects of AM fungi observed in many recent studies have drawn great interest to a possible role of AM fungi in plant-based strategies for the remediation of highly heavy-metalcontaminated soils. A greenhouse experiment using soil artificially contaminated with high concentrations of zinc, copper, lead, and cadmium showed how mycorrhizal symbiosis between Funneliformis mosseae and wheat led to significantly increased root and shoot dry weight, chlorophyll content, and total lipids [87]. Colonization of the same fungus on Triticum aestivum cv. Sardari39 plants, under four different Cadmium concentrations $(0,0.3,0.6$, and $0.9 \mathrm{mM} \mathrm{Cd})$, resulted in better growth, higher chlorophyll content, and a higher performance index (PI) for all $\mathrm{Cd}$ concentrations compared to the control. Under AM fungus inoculation, the root $\mathrm{Cd}$ content was reduced; this might be related to the metal adsorption capability of the relatively large fungal biomass (especially the extraradical hyphal cell walls) associated with the host plant's roots, which may physically minimize or prevent the entry of metals into the host plant [88]. Positive effects of mycorrhiza on wheat (Triticum durum) boron (B) uptake under extreme B concentrations were found by Sonmez et al. [89], with the plants' protection from the excessive concentration and uptake of the metal attributed to AM fungus infection.

The efficacy of two AM fungi, Rhizophagus intraradices and Claroideoglomus etunicatum, in the amelioration of As stress in wheat (Triticum aestivum L. var. HD-2967) was shown at the Botanical Garden of the Department of Botany (University of Delhi, India), where wheat plants were subjected to four levels of As (0, 25, 50, and $100 \mathrm{mg} \mathrm{As} \mathrm{kg}^{-1}$ soil). The formation of AM helped the host plant to overcome As-induced $\mathrm{P}$ deficiency, maintain a favorable $\mathrm{P} / \mathrm{As}$ ratio, and reduce arsenic-induced oxidative stress (generation of $\mathrm{H}_{2} \mathrm{O}_{2}$ and lipid peroxidation), with greater effects under a high As concentration. In addition, colonization with AMF resulted in higher activity levels of antioxidant enzymes (superoxide dismutase, catalase, and guaiacol peroxidase), higher concentrations of antioxidant molecules (carotenoids, proline, and $\alpha$-tocopherol), and increased activities of both glyoxalase I and glyoxalase II enzymes, revealing the multifarious role of AMF in the alleviation of As toxicity [90].

However, the effect of the prolonged use of agricultural inputs on mycorrhizae naturally present in the soil cannot be excluded: a very interesting experiment on wheat showed how a reduction in agricultural input, after conversion from long-term (more than 20 years) non-mycorrhizal to mycorrhizal crop cultivation, did not show any effects on AMF diversity for the next 3 years [91].

\section{Resistance to Pathogens}

AM fungi may be used as potential biological control agents for plant diseases [92,93], representing in the agriculture world a valid alternative to chemical pesticides, useful to promoting sustainability and limiting public health hazards. Indeed, AM symbiosis is acknowledged for reducing the damage caused by a wide spectrum of soil-borne pathogens, including fungi and nematodes, which often cause great yield losses [94,95]. In addition, the greater tolerance of mycorrhizal plants against root pathogens could complement innovative multiple-allele quantitative resistance obtained by plant breeding, ensuring high tolerance of plants to pathogens [4]. The mechanisms involved in this biological control seem to be related to the following:

(1) Changes in root growth and morphology: AM colonization induces notable changes in root system morphology, altering the dynamics of pathogens and modifying microbial populations, with the possible stimulation of microbiota components with antagonistic activity toward certain 
root pathogens [96]. Lucini et al. [97] showed significantly different production of exudates in AMF roots, which can influence the microbiota composition;

(2) Changes in host nutrition: the increased nutrient uptake resulting from AM symbiosis makes the plant more vigorous and, consequently, more resistant, compensating for the loss of root biomass or function caused by pathogens [98];

(3) Competition for colonization sites and photosynthates: both the AM fungi and root pathogens depends on host photosynthates, and they compete for the carbon compounds reaching the root $[99,100]$; however, AM fungi have primary access to photosynthates, and the higher carbon demand may inhibit pathogen growth [101];

(4) Activation of defense mechanisms: with AM colonization, the host plant produces a great number of phytoalexins, enzymes of the phenylpropanoid pathway, chitinases, b-1,3-glucanases, peroxidases, pathogenesis-related (PR) proteins, callose, hydroxyproline-rich glycoproteins (HRGP), and phenolics [102] that can act in biological control [103,104];

Many authors have reported that arbuscular mycorrhizal symbiosis can alleviate root disease caused by several pathogens.

After inoculation with Funneliformis mosseae on spring wheat (Triticum aestivum L.), a lower incidence of the root take-all pathogen Gaeumannomyces graminis was observed, resulting in an increase in shoot drymass and seed yield, but the best results in reducing pathogen impact were found at 4 weeks with the combined administration of the growth-promoting rhizobacteria (PGPR) Pseudomonas fluorescens strain RA56P and the arbuscular mycorrhizal fungus [105]. Equally, Triticum aestivum cv. Chinese Spring inoculated with F. mosseae revealed a broad-spectrum defense (BSD) response against Xanthomonas translucens, where genes and proteins played a regulatory role in the host immune system [106].

The importance of taking into account the inoculum type when considering the use of AMF as biocontrol agents was emphasized by Mustafa et al. [107]. Two commercially available AMF inocula (Funelliformis mosseae, Solrize ${ }^{\circledR}$ ) and one laboratory inoculum (Rhizophagus irregularis) were tested for mycorrhizal protection against Blumeria graminis sp. tritici in two moderately susceptible and resistant wheat cultivars. The highest protection level against the pathogen was obtained with F. mosseae (74\%), followed by Solrize (58\%) and R. irregularis (34\%), showing a reduction in the number of conidia with haustorium and an accumulation of polyphenolic compounds at the infection sites. The same positive result was found with the same fungus, F. mosseae, when inoculated on Triticum aestivum L., confirming both the biocontrol ability of the AMF against Blumeria graminis and the mycorrhiza-induced resistance acquired by the plant [108].

Finally, results from Falahian et al. [109] confirmed the enhancing effect of mycorrhizal fungi on Phenylalanine Ammonia Lyase (PAL) activities against Gaeumannomyces graminis in wheat plants (Triticum aestivum).

\section{Soil Aggregation}

The soil structure-defined as the particle arrangement of sand, silt, and clay, bound together into aggregates of various sizes-is a crucial aspect of the functioning of the entire ecosystem, because it represents an important source of carbon storage and, at the same time, the exchange site of water, gaseous, and nutritive flows [110]. Nowadays, intensive agricultural practices have adversely influenced the soil structure by decreasing aggregation stability, but it is currently believed that fungal hyphae are one of the main binding agents involved in stabilizing microaggregates [111] for a number of reasons that, in the past and still today, are the research subject of many scientific studies.

Firstly, extraradical hyphae ramify around plant roots, exercising a physical penetration force which compresses the soil and results in the reorientation of clay particles [112] and ramification in macroaggregate pores [113].

Secondly, another factor contributing to soil cohesion and strength is connected to the positive effect that mycorrhizal association exerts on plant water status, especially in drought conditions: the 
greater soil exploration by the fungal hyphae and, consequently, the greater cycles of water from the ground to the plant ensure greater contact between particles and organic matter [114].

Lastly, glomalin, a glycoprotein produced by AM hyphae, is hydrophobic and, thanks to its ability to coat the AM hyphae, has a key role in making the hydrophilic fungal wall able to adhere to hydrophobic surfaces located on soil particles and particulate organic matter [115]. In addition, glomalin production increases $C$ storage and $C$ availability, affecting, respectively, aggregate stability (and, hence, soil structure) [116] and the microbial population [117].

The effect in promoting aggregation is not always the same, and it depends on plant root morphologies and the association type with the fungus; the strongest effect on macroaggregation has been observed with fine roots of the host plant $(0.2-1 \mathrm{~mm}$ in diameter).

The AMF and soil exert on each other a reciprocal influence: on the one hand, as we have just said, these fungi have an effect on the formation of aggregates in the soil; on the other hand, soil quality is fundamental for the very survival of these same beneficial microorganisms. Tillage, for example, destroys the soil structure and, as a consequence, mycorrhizal hyphae. No-tillage practices along with continuous cropping systems (by eliminating fallow periods and/or growing cover crops), using mycorrhizal host crops, and reducing synthetic inputs all enhance the plant-mycorrhizal symbiotic relationship [118].

The capacity of AMF to alleviate the stressful effects of soil compaction on plant growth have been positively verified by many authors [116,119], but few experiments have been conducted specifically on wheat crops. One of these rare studies is that by Miransari et al. [120] on Triticum aestivum cv. Shiraz where, at different levels of soil compaction, inoculation with $F$. mosseae or $C$. etunicatum showed significant increases in the root, shoot $(p=0.1)$, and grain $(p=0.05)$ dry weights.

\section{Conclusions}

Over the last few years, the idea of mycorrhizae and their use in the agronomic sector has taken hold in many scientific experiments around the world. Most of the research has focused on the host plant benefits attributed to arbuscular fungi from the points of view of yield and resistance to biotic and abiotic stresses. Great efforts have been made in order to study the processes and metabolic pathways involved in the fungus, aimed at the greater absorption of nutrients and water and greater resistance to pathogens, salinity, and heavy metals. Despite the numerous studies on horticultural and forestry plants, wheat, which is one of the most important food crops worldwide, has been the subject of many tests on mycorrhizal inoculation. With a view to greater environmental sustainability, the selection and cultivation of cereals in agricultural systems with a low environmental impact could be based on the selection of wheat varieties with highly effective mycorrhizal symbiosis. In the last few years, the research has recognized notable differences in plant susceptibility and/or responsiveness to AMF among wheat genotypes that differ in ploidy number or geographic origin [121]. Significant genotypic differences were detected in the ability to form mycorrhizal symbiosis, and some significant markers, representing a Quantitative Trait Locus (QTL), were detected on wheat chromosomes [122]. Future research should therefore not focus only on the AM fungus colonization capacity, but it could take into account the ability of single grain accessions to form a mycorrhiza, based on the results obtained by previous genetic characterization. The identification of molecular markers closely associated with a mycorrhiza could be a very effective tool for selecting highly effective plants for symbiosis and developing wheat varieties suitable for low-environmental-impact agricultural systems. At the same time, the identification and selection of the most infectious and efficient mycorrhizal fungi in combination with wheat will facilitate their use as biofertilizers to overcome the loss of soil biological fertility, reduce chemical inputs, and alleviate the effects of biotic and abiotic stress.

Funding: This research received no external funding

Conflicts of Interest: The authors declare no conflicts of interest 


\section{References}

1. Frank, B. Ueber die auf Wurzelsymbiose beruhende Ernahrung gewisser Baume durch unterirdische Pilze. Ber. Der Dtsch. Bot. Ges. 1885, 3, 128-145.

2. Bonfante, P.; Giovannetti, M. Quaderni di Biologia. Le Micorrize; Piccin: Padova, Italy, 1982; pp. 1-143.

3. Pozo, M.J.; Azcon-Aguilar, C. Unraveling mycorrhiza-induced resistance. Plant Biol. 2007, 10, $393-398$. [CrossRef]

4. Gianinazzi, S.; Gollotte, A.; Binet, M.N.; van Tuinen, D.; Redecker, D.; Wipf, D. Agroecology: The key role of arbuscular mycorrhizas in ecosystem services. Mycorrhiza 2010, 20, 519-530. [CrossRef]

5. Read, D.J.; Lewis, D.H.; Fitter, A.H.; Alexander, I.J. Mycorrhizas in Ecosystems; CAB International: Wallingford, Oxon, UK, 1992.

6. Allen, M.F. The Ecology of Mycorrhizae; Cambridge Univ. Press: Cambridge, UK, 1991; p. 189.

7. Bonfante, P.; Genre, A. Mechanisms underlying beneficial plant-Fungus interactions in mycorrhizal symbiosis. Nat. Commun. 2010, 1, 48. [CrossRef]

8. Peterson, R.L.; Massicotte, H.B.; Melville, L.H. Mycorrhizas: Anatomy and cell biology. Mycologist 2004, 19, 133. [CrossRef]

9. Brundrett, M.C.; Tedersoo, L. Evolutionary history of mycorrhizal symbioses and global host plant diversity. New Phytol. 2018, 220, 1108-1115. [CrossRef]

10. Simon, L.; Bousquet, J.; Levesque, C.; Lalonde, M. Origin and diversification of endomycorrizal fungi and coincidence with vascular land plants. Nature 1993, 363, 67-69. [CrossRef]

11. Powell, C.L.; Bagyaraj, D.J. Va Mycorrhiza; CRC Press: Boca Raton, FL, USA, 1984.

12. Gadkar, V.; David-Schwartz, R.; Kunik, T.; Kapulnik, Y. Arbuscular mycorrhical fungal colonization. Factors involved in host recognition. Plant Physiol. 2001, 127, 1493-1499. [CrossRef]

13. Montero, H.; Choi, J.; Paszkowski, U. Arbuscular mycorrhizal phenotyping: The dos and don'ts. New Phytol. 2019, 221, 1182-1186. [CrossRef]

14. Aloui, A.; Recorbet, G.; Lemaître-Guillier, C.; Mounier, A.; Balliau, T.; Zivy, M.; Wipf, D.; Dumas-Gaudot, E. The plasma membrane proteome of Medicago truncatula roots as modified by arbuscular mycorrhizal symbiosis. Mycorrhiza 2018, 28, 1-16. [CrossRef]

15. Wipf, D.; Krajinski, F.; van Tuinen, D.; Recorbet, G.; Courty, P. Trading on the arbuscular mycorrhiza market: From arbuscules to common mycorrhizal networks. New Phytol. 2019, 223. [CrossRef]

16. Johns, C.D. Agricultural Application of Mycorrhizal Fungi to Increase Crop Yields, Promote Soil Health and Combat Climate Change; Future Directions international: Dalkeith, Australia, 2014.

17. Pepe, A.; Giovannetti, M.; Sbrana, C. Lifespan and functionality of mycorrhizal fungal mycelium are uncoupled from host plant lifespan. Sci. Rep. 2018, 8, 10235. [CrossRef]

18. Smith, S.E.; Smith, F.A. Roles of arbuscular mycorrhizas in plant nutrition and growth: New paradigms from cellular to ecosystem scales. Biol. Annu. Rev. Plant 2011, 62, 227-250. [CrossRef]

19. Bucher, M. Functional biology of plant phosphate uptake at root and mycorrhiza interfaces. New Phytol. 2007, 173, 11-26. [CrossRef]

20. Javaid, A. Arbuscular mycorrhizal mediated nutrition in plants. Plant Nutr. 2009, 32, 1595-1618. [CrossRef]

21. Smith, S.E.; Read, D.J. Mycorrhizal Symbiosis; Academic Press: London, UK, 2008.

22. Smith, S.; Facelli, E.; Pope, S.; Smith, F.A. Plant performance in stressful environments: Interpreting new and established knowledge of the roles of arbuscular mycorrhizas. Plant Soil 2010, 326, 3-20. [CrossRef]

23. Drew, E.A.; Murray, R.S.; Smith, S.E.; Jakobsen, I. Beyond the rhizosphere: Growth and function of arbuscular mycorrhizal external hyphae in sands of varying pore sizes. Plant Soil 2003, 251, 105-114. [CrossRef]

24. García-Garrido, J.M.; Tribak, M.; Rejón-Palomares, A.; Ocampo, J.A.; García-Romera, I. Hydrolitic enzymes and ability of arbuscular mycorrhizal fungi to colonize roots. J. Exp. Bot. 2000, 51, 1443-1448. [CrossRef]

25. Leigh, J.; Hodge, A.; Fitter, A.H. Arbuscular mycorrhizal fungi can transfer substantial amounts of nitrogen to their host plant from organic material. New Phytol. 2008, 181, 199-207. [CrossRef]

26. Pellegrino, E.; Opik, M.; Bonari, E.; Ercoli, L. Responses of wheat to arbuscular mycorrhizal fungi: A meta-analysis of field studies from 1975 to 2013. Soil Biol. Biochem. 2015, 84, 210-217. [CrossRef]

27. Ma, X.; Luo, W.; Li, J.; Wu, F. Arbuscular mycorrhizal fungi increase both concentrations and bioavilability of Zn in wheat (Triticum aestivum L) grain on Zn-spiked soils. Appl. Soil Ecol. 2019, 135, 91-97. [CrossRef] 
28. Ryan, M.H.; Angus, J.F. Arbuscular mycorrhizae in wheat and field pea crops on a low P soil: Increased Zn-uptake but no increase in P-uptake or yield. Plant Soil 2003, 250, 225-239. [CrossRef]

29. Ryan, M.H.; McInerney, J.K.; Record, I.R.; Angus, J.F. Zinc bioavailability in wheat grain in relation to phosphorus fertiliser, crop sequence and mycorrhizal fungi. J. Sci. Food Agric. 2008, 88, 1208-1216. [CrossRef]

30. Li, H.Y.; Smith, S.E.; Holloway, R.E.; Zhu, Y.G.; Smith, F.A. Arbuscular mycorrhizal fungi contribute to phosphorus uptake by wheat grown in a phosphorus-fixing soil even in the absence of positive growth responses. New Phytol. 2006, 172, 536-543. [CrossRef]

31. Al-Karaki, G.N. Field response of garlic inoculated with arbuscular mycorrhizal fungi to phosphorus fertilization. J. Plant Nutr. 2002, 25, 747-756. [CrossRef]

32. Battini, F.; Grønlund, M.; Agnolucci, M.; Giovannetti, M.; Jakobsen, I. Facilitation of phosphorus uptake in maize plants by mycorrhizosphere bacteria. Sci. Rep. 2017, 7, 4686. [CrossRef]

33. Khan, M.S.; Zaidi, A. Synergistic effects of the inoculation with plant growth promoting rhizobacteria and arbuscular mycorrhizal fungus on the performance of wheat. Turk. J. Agric. For. 2007, 31, 355-362. [CrossRef]

34. Luo, W.; Li, J.; Ma, X.; Niu, N.; Hou, S.; Wu, F. Effect of arbuscular mycorrhizal fungi on uptake of selenate, selenite, and selenomethionine by roots of winter wheat. Plant Soil 2019, 438, 71-83. [CrossRef]

35. Durán, P.; Acuna, J.J.; Jorquera, M.A. Enhanced selenium content in wheat grain by co-inoculation of selenobacteria and arbuscular mycorrhizal fungi: A preliminary study as a potential Se biofortification strategy. J. Cereal Sci. 2013, 57, 275-280. [CrossRef]

36. Blackwell, P.; Joseph, S.; Munroe, P.; Anawar, H.M.; Storer, P.; Gilkes, R.J.; Solaiman, Z.M. Influences of biochar and biochar-mineral complex on mycorrhizal colonisation and nutrition of wheat and sorghum. Pedosphere 2015, 25, 686-695. [CrossRef]

37. Saito, M.; Marumoto, T. Inoculation with arbuscular mycorrhizal fungi: The status quo in Japan and the future prospects. Plant Soil 2002, 244, 273-279. [CrossRef]

38. Plouznikoff, K.; Declerck, S.; Calonne-Salmon, M. Mitigating Abiotic Stresses in Crop Plants by Arbuscular Mycorrhizal Fungi; Springer Nature: Basel, Switzerland, 2016; pp. 341-400.

39. Kulkarni, S.; Goswami, A. Effect of Excess Fertilizers and Nutrients: A Review on Impact on Plants and Human Population. In Proceedings of the International Conference on Sustainable Computing in Science, Technology and Management (SUSCOM), Jaipur, India, 26-28 February 2019. [CrossRef]

40. Rejeb, I.; Pastor, V.; Mauch-Mani, B. Plant responses to simultaneous biotic and abiotic stress: Molecular mechanisms. Plants 2014, 3, 458-475. [CrossRef]

41. Munns, R.; Tester, M. Mechanisms of salinity tolerance. Annu. Rev. Plant Biol. 2018, 59, 651-681. [CrossRef]

42. Sairam, R.K.; Tyagi, A. Physiology and molecular biology of salinity stress tolerance in plants. Curr. Sci. 2004, 86, 407-421. [CrossRef]

43. Munns, R.; Gilliham, M. Salinity tolerance of crops-What is the cost? New Phytol. 2015, $208,668-673$. [CrossRef]

44. Latef, A.A.H.A.; Miransari, M. The Role of Arbuscular Mycorrhizal Fungi in Alleviation of Salt Stress. In Use of Microbes for the Alleviation of Soil Stresses; Springer: New York, NY, USA, 2014; Volume 2, pp. 23-38. [CrossRef]

45. Porcel, R.; Aroca, R.; Ruiz-Lozano, J.M. Salinity stress alleviation using arbuscular mycorrhizal fungi. Agron. Sustain. Dev. 2012, 32, 181-200. [CrossRef]

46. Evelin, H.; Giri, B.; Kapoor, R. Contribution of Glomus intraradices inoculation to nutrient acquisition and mitigation of ionic imbalance in NaCl-stressed, Trigonella foenum-graecum. Mycorrhiza 2012, 22, $203-217$. [CrossRef]

47. Maathuis, F.J.; Amtmann, A. $\mathrm{K}^{+}$nutrition and $\mathrm{Na}^{+}$toxicity: The basis of cellular $\mathrm{K}^{+} / \mathrm{Na}^{+}$ratios. Ann. Bot. 1999, 84, 123-133. [CrossRef]

48. Evelin, H.; Devi, T.S.; Gupta, S.; Kapoor, R. Mitigation of Salinity Stress in Plants by Arbuscular Mycorrhizal Symbiosis: Current Understanding and New Challenges. Front. Plant Sci. 2019, 10, 470. [CrossRef]

49. Jahromi, F.; Aroca, R.; Porcel, R.; Ruiz-Lozano, J.M. Influence of salinity on the in vitro development of Glomus intraradices and on the in vivo physiological and molecular responses of mycorrhizal lettuce plants. Microb. Ecol. 2008, 55, 45-53. [CrossRef]

50. Yokoi, S.; Quintero, F.J.; Cubero, B.; Ruiz, M.T.; Bressan, R.A.; Hasegawa, P.M.; Pardo, J.M. Differential expression and function of Arabidopsis thaliana $\mathrm{NHX} \mathrm{Na}{ }^{+} / \mathrm{H}^{+}$antiporters in the salt stress response. Plant $J$. 2002, 30, 529-539. [CrossRef] 
51. Sanchez, D.H.; Siahpoosh, M.R.; Roessner, U.; Udvardi, M.; Kopka, J. Plant metabolomics reveals conserved and divergent metabolic responses to salinity. Physiol. Plant. 2007, 132, 209-219. [CrossRef]

52. Talaat, N.B.; Shawky, B.T. Protective effects of arbuscular mycorrhizal fungi on wheat (Triticum aestivum L.) plants exposed to salinity. Environ. Exp. Bot. 2014, 98, 20-31. [CrossRef]

53. Abdel-Fattah, G.M.; Asrar, A.A. Arbuscular mycorrhizal fungal application to improve growth and tolerance of wheat (Triticum aestivum L.) plants grown in saline soil. Acta Physiol. Plant. 2012, 34, 267-277. [CrossRef]

54. Ibrahim, A.H.; Abdel-Fattah, G.M.; Eman, F.M.; Abd El_Aziz, M.H.; Shohr, A.E. Arbuscular mycorrhizal fungi and spermine alleviate the adverse effects of salinity stress on electrolyte leakage and productivity of wheat plants. New Phytol. 2011, 51, 261-276. [CrossRef]

55. Mathur, S.; Tomar, R.S.; Jajoo, A. Arbuscular mycorrhizal fungi (AMF) protects photosynthetic apparatus of wheat under drought stress. Photosynth. Res. 2018, 139, 227-238. [CrossRef]

56. Daei, G.; Ardekani, M.; Rejali, F.; Teimuri, S.; Miransari, M. Alleviation of salinity stress on wheat yield components, and nutrient uptake using arbuscular mycorrhizal fungi underfield conditions. J. Plant Physiol. 2009, 166, 217-225. [CrossRef]

57. Mardukhi, B.; Rejali, F.; Daei, G.; Ardakani, M.R.; Malakouti, M.J.; Miransari, M. Arbuscular mycorrhizas enhance nutrient uptake in different wheat genotypes at high salinitylevels under field and greenhouse conditions. C. R. Biol. 2011, 334, 564-571. [CrossRef]

58. Golldack, D.; Li, C.; Mohan, H.; Probst, N. Tolerance to drought and salt stress in plants: Unraveling the signaling networks. Front. Plant Sci. 2014, 5, 151. [CrossRef]

59. Kramer, P.J.; Boyer, J.S. Water Relations of Plants and Soils; Academic: New York, NY, USA, 1995.

60. Abbaspour, H.; Saeidi-Sar, S.; Afshari, H.; Abdel-Wahhab, M.A. Tolerance of mycorrhiza infected pistachio (Pistacia vera L.) seedling to drought stress under glasshouse conditions. J. Plant Physiol. 2012, 169, 704-709. [CrossRef]

61. Saraswathi, S.G.; Paliwal, K. Drought induced changes in growth, leaf gas exchange and biomass production in Albizia lebbeck and Cassia siamea seedlings. J. Environ. Biol. 2011, 32, 173-178.

62. Selmar, D.; Kleinwächter, M. Influencing the product quality by deliberately applying drought stress during the cultivation of medicinal plants. Ind. Crops Prod. 2013, 42, 558-566. [CrossRef]

63. Ruiz-Lozano, J.M.; Aroca, R.; Zamarreño, A.M.; Molina, S.; Andreo-Jiménez, B.; Porcel, R.; García-Mina, J.M.; Ruyter-Spira, C.; López-Ráez, J.A. Arbuscular mycorrhizal symbiosis induces strigolactone biosynthesis under drought and improves drought tolerance in lettuce and tomato. Plant Cell. Environ. 2016, 39, 441-452. [CrossRef]

64. Rapparini, F.; Penuelas, J. Mycorrhizal fungi to alleviate drought stress on plant growth. In Use of Microbes for the Alleviation of Soil Stress; Springer: New York, NY, USA, 2014; pp. 21-42.

65. Calvo-Polanco, M.; Sánchez-Castro, I.; Cantos, M.; García, J.L.; Azcón, R.; Ruiz-Lozano, J.M.; Beuzón, C.R.; Aroca, R. Effects of different arbuscular mycorrhizal fungal backgrounds and soils on olive plants growth and water relation properties under well-watered and drought conditions. Plant. Cell. Environ. 2016, 39, 2498-2514. [CrossRef]

66. Symanczik, S.; Lehmann, M.F.; Wiemken, A.; Boller, T.; Courty, P.E. Effects of two contrasted arbuscular mycorrhizal fungal isolates on nutrient uptake by Sorghum bicolor under drought. Mycorrhiza 2018, 28, 779-785. [CrossRef]

67. Dar, Z.M.; Masood, A.; Asif, M.; Malik, M.A. Review on arbuscular mycorrhizal fungi: An approach to overcome drought adversities in plants. Int. J. Curr. Microbiol. Appl. Sci. 2018, 7, 1040-1049. [CrossRef]

68. Jiménez Zacarías, J.J.; Altamirano-Hernández, J.; Peña Cabriales, J.J. Nitrogenase activity and trehalose content of nodules of drought-stressed common beans infected with effective (Fix+) and ineffective (Fix-) rhizobia. Soil Biol. Biochem. 2004, 36, 1975-1981. [CrossRef]

69. Farías-Rodríguez, R.; Mellor, R.B.; Arias, C.; Peña Cabriales, J.J. The accumulation of trehalose in nodules of several cultivars of common bean (Phaseolus vulgaris) and its correlation with resistance to drought stress. Physiol. Plant 1998, 102, 353-359. [CrossRef]

70. Ruiz-Lozano, J.M. Arbuscular mycorrhizal symbiosis and alleviation of osmotic stress. New perspectives for molecular studies. Mycorrhiza 2003, 13, 309-317. [CrossRef]

71. Li, T.; Hu, J.L.; Hao, Z.P.; Li, H.; Wang, Y.S.; Chen, B.D. First cloning and characterization of two functional aquaporin genes from an arbuscular mycorrhizal fungus Glomus intraradices. New Phytol. 2013, 197, 617-630. [CrossRef] 
72. Jia-Dong, H.; Tao, D.; Hui-Hui, W.; Zou, Y.N.; Wu, Q.S.; Kamil, K. Mycorrhizas induce diverse responses of root TIP aquaporin gene expression to drought stress in trifoliate orange. Sci. Hortic. 2019, 243, 64-69. [CrossRef]

73. Amanifar, S.; Khodabandeloo, M.; Fard, E.M.; Askari, M.S.; Ashrafi, M. Alleviation of salt stress and changes in glycyrrhizin accumulation by arbuscular mycorrhiza in liquorice (Glycyrrhiza glabra) grown under salinity stress. Environ. Exp. Bot. 2019, 160, 25-34. [CrossRef]

74. Ouledali, S.; Ennajeha, M.; Ferrandino, A.; Khemiraac, H.; Schubert, A.; Secchi, F. Influence of arbuscular mycorrhizal fungi inoculation on the control of stomata functioning by abscisic acid (ABA) in drought-stressed olive plants. S. Afr. J. Bot. 2019, 121, 152-158. [CrossRef]

75. Bernardo, L.; Carletti, P.; Badeck, F.W.; Rizza, F.; Morcia, C.; Ghizzoni, R.; Rouphael, Y.; Colla, G.; Terzi, V.; Lucini, L. Metabolomic responses triggered by arbuscular mycorrhiza enhance tolerance to water stress in wheat cultivars. Plant Physiol. Biochem. 2019, 137, 203-212. [CrossRef]

76. Beltrano, J.; Ronco, M. Improved tolerance of wheat plants (Triticum aestivum L.) to drought stress and rewatering by the arbuscular mycorrhizal fungus Glomus claroideum: Effect on growth and cell membrane stability. Braz. J. Plant Physiol. 2008, 20, 29-37. [CrossRef]

77. Al-Karaki, G.; McMichael, B.; Zak, J. Field response of wheat to arbuscular mycorrhizal fungi and drought stress. Mycorrhiza 2004, 14, 263-269. [CrossRef]

78. Al-Karaki, G.N.; Al-Omoush, M. Wheat response to phosphogypsum and mycorrhizal fungi in alkaline soil. J. Plant Nutr. 2002, 25, 873-883. [CrossRef]

79. Solaiman, Z.M.; Blackwell, P.; Abott, L.K.; Storer, P. Direct and residual effect of biochar application on mycorrhizal root colonization, growth and nutrition of wheat. Soil Res. 2010, 48, 546-554. [CrossRef]

80. Ghori, N.H.; Ghori, T.; Hayat, M.Q.; Imadi, S.R.; Gul, A.; Altay, V.; Ozturk, M. Heavy metal stress and responses in plants. Int. J. Environ. Sci. Technol. 2019, 16, 1807-1828. [CrossRef]

81. Srinivas, J.; Purushotham, A.V.; Murali Krishna, K.V.S.G. The effects of heavy metals on seed germination and plant growth on Coccinia, Mentha and Trigonella plant seeds in Timmapuram. Int. Res. J. Environ. Sci. 2013, 2, 20-24.

82. Nichols, P.B.; Couch, J.D.; Al Hamdani, S.H. Selected physiological responses of Salvinia minima to different chromium concentrations. Aquat. Bot. 2000, 68, 313-319. [CrossRef]

83. Mehmood, A.; Mirza, M.A.; Choudhary, M.A.; Kim, K.H.; Raza, W.; Raza, N.; Lee, S.S.; Zhang, M.; Lee, J.H.; Sarfraz, M. Spatial distribution of heavy metals in crops in a wastewater irrigated zone and health risk assessment. Environ. Res. 2019, 168, 382-388. [CrossRef] [PubMed]

84. Joner, E.J.; Briones, R.; Leyval, C. Metal-binding capacity of arbuscular mycorrhizal mycelium. Plant Soil 2000, 226, 227-234. [CrossRef]

85. Wright, S.F.; Upadhyaya, A. A survey of soils for aggregate stability and glomalin, a glycoprotein produced by hyphae of arbuscular mycorrhizal fungi. Plant Soil 1998, 198, 97-107. [CrossRef]

86. Gomathy, M.; Sabarinathan, K.G.; Thangaraju, M.; Subramanian, K.S.; Sivashankari Devi, T.; Ananthi, K. The effect of mycorrhizae inoculated maize root exudates in alleviation of chromium toxicity in chromium polluted environments. Insight Microbiol. 2011, 1, 20-30. [CrossRef]

87. Rabie, G.H. Contribution of arbuscular mycorrhizal fungus to red kidney and wheat plants tolerance grown in heavy in metal polluted soil. Afr. J. Biotechnol. 2005, 4, 332-345.

88. Shahabivand, S.; Maivan, H.Z.; Goltapeh, E.M.; Sharifi, M.; Aliloo, A.A. The effects of root endophyte and arbuscular mycorrhizal fungi on growth and cadmium accumulation in wheat under cadmium toxicity. Plant Physiol. Biochem. 2012, 60, 53-58. [CrossRef]

89. Sonmez, O.; Aydemir, S.; Kaya, C. Mitigation effects of mycorrhiza on boron toxicity in wheat (Triticum durum) plants. N. Z. J. Crop Hortic. Sci. 2009, 37, 99-104. [CrossRef]

90. Sharma, S.; Anand, G.; Singh, N.; Kapoor, R. Arbuscular Mycorrhiza augments arsenic tolerance in wheat (Triticum aestivum L.) by strengthening antioxidant defense system and thiol metabolism. Front. Plant Sci. 2017, 8, 906. [CrossRef]

91. Berruti, A.; Bianciotto, V.; Lumini, E. Seasonal variation in winter wheat field soil arbuscular mycorrhizal fungus communities after non-mycorrhizal crop cultivation. Mycorrhiza 2018, 28, 535-548. [CrossRef] 
92. Bagy, H.M.M.K.; Hassan, E.A.; Nafady, N.A.; Dawood, M.F.A. Efficacy of arbuscular mycorrhizal fungi and endophytic strain Epicoccum nigrum ASU11 as biocontrol agents against blackleg disease of potato caused by bacterial strain Pectobacterium carotovora subsp. atrosepticum PHY7. Biol. Control 2019, 134, 103-113. [CrossRef]

93. Nguvo, K.J.; Gao, X. Weapons hidden underneath: Bio-control agents and their potentials to activate plant induced systemic resistance in controlling crop Fusarium diseases. J. Plant Dis. Prot. 2019, 126, 177-190. [CrossRef]

94. Sharma, I.P.; Sharma, K. Mycorrhizal colonization and phosphorus uptake in presence of PGPRs along with nematode infection. Symbiosis 2018, 77, 185-187. [CrossRef]

95. De la Peña, E.; Echeverría, S.R.; van der Putten, W.H.; Freitas, H.; Moens, M. Mechanism of control of root-feeding nematodes by mycorrhizal fungi in the dune grass Ammophila arenaria. New Phytol. 2006, 169, 829-840. [CrossRef]

96. Barea, J.M.; Pozo, M.J.; Azcon, R.; Aguilar, C.A. Microbial co-operation in the rhizosphere. J. Exp. Bot. 2005, 56, 1761-1778. [CrossRef]

97. Lucini, L.; Colla, G.; Miras Moreno, M.B.; Bernardo, L.; Cardarelli, M.; Terzi, V.; Bonini, P.; Rouphaelf, Y. Inoculation of Rhizoglomus irregulare or Trichoderma atroviride differentially modulates metabolite profiling of wheat root exudates. Phytochemistry 2019, 157, 158-167. [CrossRef]

98. Tahat, M.M.; Sijam, K.; Othman, R. Mycorrhizal fungi as a biological control agent. Plant Pathol. J. 2010, 9 , 198-207. [CrossRef]

99. Smith, G.S. Interactions of nematodes with mycorrhizal fungi. In Vistas on Nematology; Society of Nematology: Hyattsville, MD, USA, 1987; pp. 292-300.

100. Linderman, R.G. Role of VAM fungi in biocontrol. In Mycorrhizae and Plant Health; APS: St Paul, Brazil, 1994; pp. 1-26.

101. Azcòn-Aguilar, C.; Barea, J.M. Arbuscular mycorrhizas and biological control of soil-borne plant pathogens: An overview of the mechanisms involved. Mycorrhiza 1996, 6, 457-464. [CrossRef]

102. Gianinazzi-Pearson, V.; Gollotte, A.; Dumas-Gaudot, E.; Franken, P.; Gianinazzi, S. Gene expression and molecular modifications associated with plant responses to infection by arbuscular mycorrhizal fungi. In Advances in Molecular Genetics of Plant-Microbe Interactions; Daniels, M., Downic, J.A., Osbourn, A.E., Eds.; Kluwer Academic Publishers: Dordrecht, The Netherlands, 1994; pp. 179-186.

103. Jung, S.C.; Martinez-Medina, A.; Lopez-Raez, J.A.; Pozo, M.J. Mycorrhiza-induced resistance and priming of plant defenses. J. Chem. Ecol. 2012, 38, 651-654. [CrossRef]

104. Siddiqui, Z.A. PGPR: Biocontrol and Biofertilization; Springer: Dordrecht, The Netherlands, 2006.

105. Behn, O. Influence of Pseudomonas fluorescens and arbuscular mycorrhiza on the growth, yield, quality and resistance of wheat infected with Gaeumannomyces graminis. J. Plant Dis. Prot. 2008, 115, 4-8. [CrossRef]

106. Fiorilli, V.; Vannini, C.; Ortolani, F.; Garcia-Seco, D.; Chiapello, M.; Novero, M.; Domingo, G.; Terzi, V.; Morcia, C.; Bagnaresi, P.; et al. Omics approaches revealed how arbuscular mycorrhizal symbiosis enhances yield and resistance to leaf pathogen in wheat. Sci. Rep. 2018, 8, 9625. [CrossRef] [PubMed]

107. Mustafa, G.; Randoux, B.; Tisserant, B.; Fontaine, J.; Magnin-Robert, M.; Sahraoui, A.L.; Reignault, P.H. Phosphorus supply, arbuscular mycorrhizal fungal species, and plant genotype impact on the protective efficacy of mycorrhizal inoculation against wheat powdery mildew. Mycorrhiza 2016, 26, 685-697. [CrossRef] [PubMed]

108. Mustafa, G.; Khong, N.G.; Tisserant, B.; Randoux, B.; Fontaine, J.; Magnin-Robert, M.; Reignault, P.; Sahraoui, A.L. Defence mechanisms associated with mycorrhiza-induced resistance in wheat against powdery mildew. Funct. Plant Biol. 2017, 44, 443-454. [CrossRef]

109. Falahian, F.; Ardebili, Z.O.; Fahimi, F.; Khavarinejad, R. Effect of Mycorrhizal Fungi on Some Defense Enzymes against Gaeumannomyces gaminis in Wheat. Pak. J. Biol. Sci. 2007, 10, 2418-2422. [CrossRef]

110. Bronick, C.J.; Lal, R. Soil structure and management: A review. Geoderma 2005, 124, 3-22. [CrossRef]

111. Miller, R.M.; Jastrow, J.D. Mycorrhizal fungi influence soil structure. In Arbuscular Mycorrhizas: Molecular Biology and Physiology; Kapulnik, Y., Douds, D.D., Eds.; Kluwer Academic Publishers: Dordrecht, The Netherlands, 2000; pp. 3-18.

112. Rilling, M.C.; Mummey, D.L. Mycorrhizas and soil structure. New Phytol. 2006, 171, 41-53. [CrossRef]

113. Six, J.; Feller, C.; Denef, K.; Ogle, S.M.; Sa, J.C.; Albrecht, A. Soil organic matter, biota and aggregation in temperate and tropical soils-Effects of no-tillage. Agronomie 2002, 22, 755-775. [CrossRef] 
114. Six, J.; Bossuyt, H.; Degryze, S.; Denef, K. A history of research on the link between (micro) aggregates, soil biota, and soil organic matter dynamics. Soil Tillage Res. 2004, 79, 7-31. [CrossRef]

115. Cardoso, I.M.; Kuyper, T.W. Mycorrhizas and tropical soil fertility. Agric. Ecosyst. Environ. 2006, 116, 72-84. [CrossRef]

116. Miransari, M. Contribution of arbuscular mycorrhizal symbiosis to plant growth under different types of soil stress. Plant Biol. 2010, 1, 563-569. [CrossRef]

117. Bai, C.; He, X.; Tang, H.; Shan, B.; Zhao, L. Spatial distribution of arbuscular mycorrhizal fungi, glomalin and soil enzymes under the canopy of Astragalus adsurgens Pall. in the Mu Us sandland, China. Soil Biol. Biochem. 2009, 41, 941-947. [CrossRef]

118. Nichols, K.A.; Wright, S.F. Contributions of soil fungi to organic matter in agricultural soils. In Functions and Management of Soil Organic Matter in Agroecosystems; Magdoff, F., Weil, R., Eds.; CRC Press: Boca Raton, FL, USA, 2004; pp. 179-198.

119. Rillig, M.C.; Wright, S.F.; Eviner, V.T. The role of arbuscular mycorrhizal fungi and glomalin in soil aggregation: Comparing effects of five plant species. Plant Soil 2001, 238, 325-333. [CrossRef]

120. Miransari, M.; Bahrami, H.A.; Rejali, F.; Malakouti, M.J. Using arbuscular mycorrhiza to reduce the stressful effects of soil compaction on wheat (Triticum aestivum L.) growth. Soil Biol. Biochem. 2008, 40, 1197-1206. [CrossRef]

121. De Vita, P.; Avio, L.; Sbrana, C.; Laidò, G.; Marone, D.; Mastrangelo, A.M.; Cattivelli, L.; Giovannetti, M. Genetic markers associated to arbuscular mycorrhizal colonization in durum wheat. Sci. Rep. 2018, 8, 10612. [CrossRef]

122. Lehnert, H.; Serfling, A.; Enders, M.; Friedt, W.; Ordon, F. Genetics of mycorrhizal symbiosis in winter wheat (Triticum aestivum). New Phytol. 2017, 215, 779-791. [CrossRef]

(C) 2019 by the authors. Licensee MDPI, Basel, Switzerland. This article is an open access article distributed under the terms and conditions of the Creative Commons Attribution (CC BY) license (http://creativecommons.org/licenses/by/4.0/). 